\title{
The implementation of Cognitive Strategy Instruction in Writing (CSIW) strategy in teaching writing for the eight grade students at Mts Al-Karomah Winong Ngawi
}

\author{
Ita Karlinasari \\ Department of English Teaching, Universitas PGRI Madiun, Indonesia
}

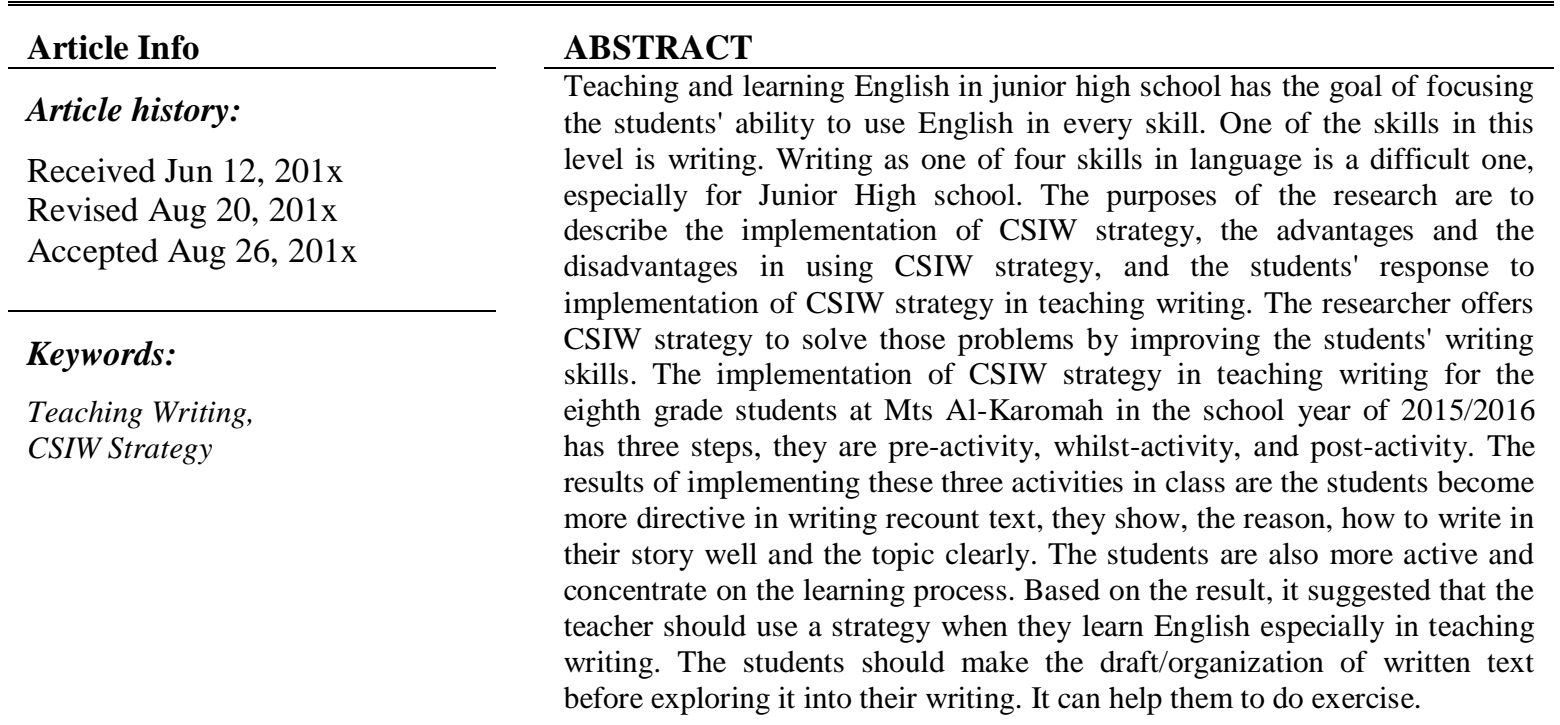

Copyright (C) 2019 Department of English Teaching. All rights reserved.

\author{
Corresponding Author: \\ Ita Karlinasari \\ Department of English Teaching, Faculty of Teacher Training and Education \\ Universitas PGRI Madiun \\ Jalan Setiabudi No.85 Madiun \\ Email: itaanwar23@gmail.com
}

\section{INTRODUCTION}

Nowadays, English is learned in all levels of school in Indonesia, such as in Junior high school. Teaching and learning English in junior high school has the goal on focusing the students able to use English in every skill. One of the skills that must be studied in this level is writing. Writing is a difficult skill because it requires the ability to spell, master grammar, or structure, and the ability to use the vocabulary. Therefore, the teacher need to practice writing skills to make the writing good and right. It means that writing is one of English skills for students in teaching learning process and it's used by students to improve their knowledge. It is the most pay attention to a number of aspects such as content, grammatical function, vocabulary, lexical items, mechanism like punctuation, and organization. The students are usually still difficult to develop their mindset to express to write, they are still confused and weak in making a sentence in English.

In the practice language teaching, the teacher has to use strategy. Strategy is certain planned designs by controlling and manipulating. It is important to help the teacher in preparing and evaluating teaching learning process. In teaching writing process, some strategy can be used in the learning process. Among the strategy, one of them is Cognitive strategy instruction in writing (CSIW) strategy. This strategy used in the teaching process to improve students written English. In this way the students are not confused in writing recount text, because they will be helped to solve the problem, especially how to write sentences or text.

Writing is the difficult subject in the school since the students have to produce a text by using English. So, the teacher must create the subject so that the students can study the subject easily. According to Sokolik (in Linse and Nunan, 2005: 98), "Writing is a combination of process and product". Moreover, Olson 
(in Linse and Nunan, 2005: 98) suggests that, "Writing is the process refers to the act of gathering ideas and working with them until they are presented in a manner that is polished and comprehensible to the reader. The concept that writing is a process is very useful". From the theories above writing is an activity that we do to collect a variety of patterns of thought to make a work that is a written text as possible and can be understood by the readers. Writing is an activity that is used to communicate with others. According Broughton at al (1980: 116) says, "Writing differs from that of talking in that it is less spontaneous and more permanent, and the resources which are available for communication are fewer because we cannot as we do in conversation interact with the listener and adapt as we go along." In line with the theory above that, writing is a communication that is used by a people to other people. Writing requires good skills that the others are able to understand the message in the text. So writing must be done carefully and correctly.

In fact, based on the writer's interview with teacher at MTs Al Karomah Winong, the writer found the problem that: first, the students are usually still difficult to develop their mindset to express to write, they are still confused and weak in making a sentence in English. Second, the students tended to have mistaken such as; content, grammatical function, vocabulary, lexical items, mechanism like punctuation, and organization. The problems make the students frustrated so that they tend to stop their writing. By using Cognitive strategy instruction in writing (CSIW) strategy is expected to make the learning process more interesting and enjoyable. It will also motivate students in the learning process. In teaching writing skill, teachers as an educator have to use good strategy in teaching learning process. From the explanantion above the researcher takes research entitled: "The Implementation of Cognitive Strategy Instruction in Writing (CSIW) Strategy in Teaching Writing for the Eight Grade Students At MTs AL-KAROMAH Winong, Ngawi in schooling year 2015/2016".

\section{RESEARCH METHOD}

The approach and type of this study use qualitative research and descriptive qualitative. Qualitative research has been defined in a variety of ways. Berg (2001: 3) states that "Popular qualitative research additionally includes such methods as observation of experimental natural settings, photographic techniques (including, videotaping), historical analysis (historiography), document and textual analysis, sociometry, sociodrama and similar ethnomethodological experimentation, ethnographic research, and a number of unobtrusive techniques". It means that qualitative research conducted with the observation of an experiment to get the data. This qualitative research categorizes as descriptive qualitative. According to Vanderstop and Johnstom (2009: 36), "A common descriptive research technique is naturalistic observation, which involves collecting data where people are ordinarily found". From the explanation above, means that design of qualitative research is directed to describe the problem based on the data which is collected naturally.

Data is a part that is separate with research activity. The sources of data in this research consist of social situation, participant, document, and sampling technique. In this study, the writer uses interview, observation, and documentation as the data collection technique. In this research, the writer interview the English teacher and the eighth grade students of A class in MTs Al Karomah Winong. The writer's uses unstructured interview in this study because the writer asks some questions to the students and they are freely answer the question without thinking the pattern of answer. In this study, the writer uses participant observation because the writer herself observe what happens in the class during the learning process. So, the position of the writer is observer. The research is done during teaching writing by using CSIW strategy in the eighth grade students of A class in MTs Al Karomah Winong. In this study, the document is syllabus, lesson plan,students score, a name list and worksheets that are used for teaching and learning English of the eighth grade students MTs AL-KAROMAH Winong, Ngawi.

In this study, the writer uses a triangulation technique and uses one of type of triangulation, methodological triangulation. In methodological triangulation, the writer examines the validity of the data using some methods of collecting the data, namely: observation, interview, and documentation. In technique of data analysis, researcher uses the interactive analysis models by Miler, et.al (2014: 31). They are data condensation, data display, and conclusion/ verification.

\section{RESULTS AND DISCUSSION}

Research finding are presents from data presentation. From the explanation of data presentation above, the research finding is described as follows: 1). The Implementation of Cognitive strategy instruction in writing (CSIW) strategy in teaching writing for eight grade students at MTs AL-KAROMAH Winong, Ngawi in the Schooling Year 2015/2016. They are some steps in teaching and learning process, the steps of 
teaching and learning are as follows: first, pre-activities, the teacher did some activities before discussing the lesson. Second, whilst activities the teacher did the main activities in the process of teaching and learning. There are three steps in this activity, they are exploration, elaboration, and confirmation. Third, post activities the teacher asked some questions to the students about students' difficulties during the lesson. 2). The advantages and disadvantages of implementation of Cognitive Strategy Instruction in Writing (CSIW) strategy in teaching writing are as follows: a) CSIW strategy increase students' concentration. b) CSIW strategy makes the students' writing assignment more directional from making of draft/organization of written text or before explored it into their writing. c) CSIW strategy makes the students get new knowledge and new experiences in the learning to write recount text. From this research, the researcher also finds the disadvantages in the implementation of CSIW strategy. They are presented as follows: a) CSIW strategy makes the students who do not focus are rather difficult to understand the CSIW strategy especially the editing and revising. b) CSIW strategy takes a lot of time and it makes the students feel they do some assignment. They have to make the plan think sheet, organize think sheet, edit and revise think sheet and then write their experience or recount text.

The students' response to implementation of Cognitive Strategy Instruction in Writing (CSIW) strategy in teaching writing such as: CSIW strategy makes the students become more active in learning the process and CSIW strategy makes the students are very enthusiastic during the learning process. Before starting to teach, the teacher should have some preparations in which the teacher and the students will need in this activity. First, the teacher explains about the generic structure of recount text and the teacher gives the students example of recount text that must be discussed by the students. The teacher asked students to write and identify the generic structures based on the example and evaluate it. Second, the teacher gives the example how to write the text by using CSIW strategy and the teacher practice it. Next, the teacher modeled for the students how to organize the categories of recount text. And then, the teacher modeled how to transform the organized ideas into well-formed categories or the generic structure text and the teacher explains how to transform notes and phrases from the organizer into well-formed sentences. After drafting the generic structures of recount text, the teacher modeled self-editing using checklist by starring the parts of the paper and the teacher modeled how to monitor and revise the text.

The third, the teacher asks the students to think aloud the theme of the text they will used. The fourth. the teacher explains and gives the example how to write recount text. The fifth and sixth procedures, the teacher monitors the students work and the teacher asks the students to mention 5 steps of strategies that are related to planning, organizing, writing, editing and revising the text. The seventh procedures, the teacher guided the students in the writing process. Students are given 3 blank papers. The last procedures, the teacher asks the students to do all aspects of writing process independently. The students finish the text and read aloud in front of the class. Based on the explanation above, it can be concluded that the teacher explanation and the theory of Guzel Ruya and Ozmen (2006: 287).

The results of implementing these 3 activities in class are the students become more directive in writing recount text, they show, the reason, how to write in their story well and the topic clearly. The students are also more active and concentrate on the learning process.

\section{CONCLUSION}

Based on the discussion on the previous chapter, the writer takes some conclusion. The researcher concludes the implementation of the strategy has three steps included pre-activities, whilstactivities, and post-activities. In pre-activities, the teacher greets to open the lesson, checks students' attendance list, give the students apperception. The teacher does some activities in whilst-activities. First activities, the teacher explains about the generic structure of recount text and the teacher gives the students example of recount text. The teacher asks students to write and identify the generic structures based on the example and evaluate it. Second, the teacher gives the example how to write the text by using CSIW strategy and the teacher practice it. Third, the teacher asks the students to think aloud the theme of the text they will use. After that, the teacher explains and gives the example how to write recount text. Then, the teacher monitors the students work and the teacher asks the students to mention 5 steps of strategies that are related to planning, organizing, writing, editing and revising the text. After that, the teacher guides the students in the writing process. Students are given 3 papers. The last, the teacher asks the students to do all aspects of writing process independently. The students finish the text and read aloud in front of the class.

The teacher does some activities in the post-activities. The teacher asks some questions to review the material and students' difficulties during the lesson. Finally, the teacher closes the teaching and 
learning the process by praying and greeting. The result of interview shows that CSIW strategy can be applied successfully in teaching writing recount text in the MTs AL-KAROMAH Winong.

There are some advantages and disadvantages of implementation Cognitive strategy instruction in writing (CSIW) strategy in teaching writing for eight grade students at MTs AL-KAROMAH Winong, Ngawi in the Schooling Year 2015/2016. The advantages are: a) CSIW strategy increase students' concentration, because the students felt this strategy is not easy for them so they need to concentrate and pay attention; b) CSIW strategy makes the students' writing assignment more directional from making of draft/organization of written text or before explored it into their writing; c) CSIW strategy makes the students get new knowledge and new experiences in the learning to write recount text. It can be concluded that CSIW strategy is suitable to apply to the eighth-grade students of MTs AL-KAROMAH Winong. CSIW strategy gives a good effect for the students, especially in writing ability.

The disadvantages from this study are: a) CSIW strategy makes the students who do not focus are rather difficult to understand the CSIW strategy especially the editing and revising; b) CSIW strategy takes a lot of time and it makes the students feel they do some assignment. They have to make the plan think sheet, organize think sheet, edit and revise think sheet and then write their experience or recount text.

There are also some students' responses of implementation Cognitive strategy instruction in writing (CSIW) strategy in teaching writing for eight grade students at MTs AL-KAROMAH Winong, Ngawi in the Schooling Year 2015/2016. The students' responses during the teaching and learning process using CSIW strategy are: a) CSIW strategy makes the students become more active in learning the process, they will be asked when they don't understand with CSIW strategy; b) CSIW strategy makes the students are very enthusiastic during the learning process.

Future Researchers are recommended to use CSIW strategy that can make attract the students, especially in writing skill. It can also make students more active and enthusiastic to make and write a recount text. So, the future researcher is expected to conduct another research that has different perspective from this research.

\section{REFERENCES}

Berg, B. L. (2001). Qualitative Research Method for The Social Sciences. California State University: Long Beach.

Broughton, G. B., Christopher, F.R., Hill, P., and Pincas, A. (1980). Teaching English as a Foreign Language. USA and Canada: Routledge.

Brown, H. D. (2007). Principles of Language Learning and Teaching. New York: Addison Wesley Longman, Inc.

Brown, H. D. (2000). Teaching by Principles an Interactive Approach to Language Pedagogy. California: Wesley Longman, Inc.

Cahyono, B. Y. (2011). Teaching English by Using Various Text Types. Malang: State University of Malang Press.

Guzel, R and O, O. (2006). The Effectiveness of Modified Cognitive Strategy Instruction in Writing With Mildly Mentally Retarded Turkish Students. Gazi University.

Brown, H. D (1998). How to Teach English Language Teaching. UK: Cambridge.

Brown, H. D. (2001). The Practice of English Language Teaching. Third Edition. UK: Cambridge.

Hallenbeck, M. J. (2002). Taking Charge: Adolescents With Learning Disabilities Assume Responsibility For Their Own Writing.United States: International Reading Association, Inc.

Knuuttila H. (2010). Written Expression Instruction For Elementary Students With Learning Disabilities: A Review Of Literature. At Northern Michigan University.

Linse, C T., \& David, N. (2005). Practical English Language Teaching: Young Learners. New York: mcGraw-Hill.

Nera. (2004). Expanding The Writing Process To Accommodate Students With Learning Disabilities. England: Central,CorrecticutUnivertsity Press. 
Sugiyono. (2014). Memahami Penelitian Kualitatif. Bandung: Alfabeta.

Vanderstop, Scott W and Johnston, Deirdre D. 20009. Research Methods For Everyday Life Blending Qualitative And Quantitative Approaches. USA: Clearance Center. Inc. 